\title{
OSOBITOSTI I PORIJEKLO SPLITSKOG SAKRAMENTARA
}

\author{
Domagoj Volarević
}

Sveučilište u Splitu

Katolički bogoslovni fakultet

domagoj.volarevic@du.t-com.hr
UDK: 091.14:27-523.41(497.583Split)“11 “ https://doi.org/10.34075/cs.54.4.1 Izvorni znanstveni rad Rad zaprimljen 3/2019.

\section{Sažetak}

Vrlo dragocjen srednjovjekouni rukopisni kodeks, koji se čuva u katedralnom arhivu splitske prvostolnice, a koji je mo. Šime Marović tipologizirao ga jekao aakramentar, često je dosad bio predmetom studija raznih znanstvenika. Spoznaje o njemu i njegovim vlastitostima polako su se nadopunjavale. Kakoje riječ o liturgijskoj knjizi, neobično je što je liturgijski vid ove jedinstvene knjige nedovoljno istražen. Uz zaključke do kojih se došlo dosadašnjim istraživanjem i studijama, ostalo je i mnogo otvorenih pitanja. Jedno od njih je i porijeklo Sakramentara. Dosada je bila uobičajena hipoteza da ga je vjerojatno u Split iz Bologne donio nadbiskup Bernardo. Detaljnom analizom liturgijske i kodikološke strukture Sakramentara te otkrićima njegovih iznimnih, štoviše, jedinstvenih vlastitosti, došli smo do zaključaka o porijeklu ove knjige, o liturgijskim utjecajima koji su velikim dijelom oblikovali njezin sadržaj te naposljetku i o tome kakoje Sakramentar stigao do Splita.

Ključne riječi: Splitski sakramentar, kodeks, rimska liturgija, galikanska liturgija, hispano-mozarapska liturgija

\section{UVOD}

U riznici splitske katedrale jedno od značajnijih mjesta zauzima srednjovjekovni rukopisni kodeks pisan na pergameni, označen kataloškim brojem Cod. 624 (raniji kataloški broj bio je 127). ${ }^{1}$ Rukopis je prije bio označen kao misal, ali je posljednjih tridesetak godina poznat kao Sacramentarium Spalatense, Splitski sakramentar (u daljnjem tekstu označavamo ga kao St). Preciznija tipologija u

\footnotetext{
1 Na listiću zalijepljenom s unutarnje strane drvene korice napisano je: Archivium
} capituli cathedrali Spalatensis, no. 624, scr. D. 
odnosu na prethodnu plod je istraživanja mons. mo. Šime Marovića, kapelnika splitske katedrale, o čemu će u radu još biti riječi. Kodeks je i dalje vrlo zanimljivo vrelo ne samo s glazbenoga ili umjetničkoga i povijesnoga gledišta nego ponajprije s liturgijskoga gledišta. Osim samoga kodeksa St koji smo detaljno istražili, također smo za naše istraživanje razmotrili i dosadašnje spoznaje o St. Promatrajući ih kritički kroz prizmu liturgijske kodikologije i kritike, pokušavali smo otkriti neke dosad nepoznate detalje koji se tiču njegove prošlosti, ali i liturgijske strukture. Detaljnija liturgijska analiza kodeksa, rađena prema suvremenim standardima kodikologije i općenito liturgijske znanosti, pokazala je tako neke dosad nepoznate liturgijske značajke i osobitosti ovoga kodeksa te nas u konačnici uputila i prema spoznaji o mjestu njegova nastanka te redefiniciji hipoteze o njegovu dolasku u Split gdje se i danas čuva. ${ }^{2}$

\section{OPIS KODEKSA}

Dosadašnji proučavatelji dosta su dobro opisali kodeks s povijesno-umjetničkog i djelomično s liturgijskog aspekta. Osvrnut ćemo se kratko na najznačajnije studije o kodeksu St, čije su nam spoznaje dijelom poslužile kao polazište $u$ našem istraživanju.

\subsection{Dosadašnje spoznaje}

Kodeks St dobro je poznat u znanstvenom krugu, ne samo u Hrvatsko nego i izvan njenih granica. Dosadašnja istraživanja i studije su potvrdile da se radi o vrlo vrijednoj knjizi sa povijesnoga i umjetničkoga aspekta, značajnoj za sam grad Split, ali i šire područje.

Prva studija u kojoj je moguće pronaći kraće opise kodeksa $\mathbf{S t}$ je iz 19. stoljeća - Vodja po Spljetu i Solinu, autori - Jelić, Bulić i Rutar. ${ }^{3}$ Kontekst toga prikaza potrebno je gledati unutar obnovljenoga zanimanja historigrafije za povijest Hrvata u srednjem vijeku. Time se pokušalo, po našem mišljenju, legitimno, visoko u kulturološkom i umjetničkom i crkvenom smislu vrednovati hrvatsko srednjovjekovlje. Nadalje ga spominje i H. Folnesics u svome djelu Die illuminierten Handschriften in Dalmatien - Iluminirani rukopisi u Dalmaciji. ${ }^{4}$

2 Istraživanje za ovaj rad dijelom je financirala Hrvatska zaklada za znanost $\mathrm{u}$ okviru projekta IP 6619 Cromuscodex70.

3 Usp. L. Jelić - F. Bulić - S. Rutar, Vodja po Spljetu i Solinu, Tiskara S. Artala, Zadar, 1894.

4 Usp. H. Folnesics, Die illuminierten Handschriften in Dalmatien, Leipzig, 1917. 
Otprilike $\mathrm{u}$ isto vrijeme V. Novak se bavi srednjovjekovnim kodeksima s područja Hrvatske. Dok je Folnesicseva studija usmjerena na minijature $u$ rukopisima, Novakov se nadasve zanima za paleografiju, pogotovo za prisustvo i razvoj beneventanskoga pisma $\mathrm{u}$ južnoj Hrvatskoj. Novak predstavlja St kao kao jedan od rukopisa koji su ili pisani benevantanom ili se u njima nalazi beneventana. ${ }^{5}$ Novak je očito upoznat s Folnesicsevim radom, na temelju kojega govori o povijesti beneventane u južnoj Hrvatskoj. Što se tiče konkretnijih podataka o St značajka je Novakova istraživanja da prvi put na temelju znanstvenih činjenica donosi hipotezu o porijeklu ovoga kodeksa. ${ }^{6}$ On pretpostavlja da je $\boldsymbol{S t}$, u to doba još uvijek označavan kao missale, nastao u Italiji, vjerojatno u Ravenni: krajem 12. stoljeća splitski nadbiskup Bernard, koji je porijeklom iz Ravenne, darovao bi ga Splitskoj Crkvi. Nakon toga kodeksu su pridodana dva pergamenska lista pisana beneventanom (glavni razlog Novakova interesa za St), koji su ostatak jednoga mnogo starijeg sakramentara. ${ }^{7}$ Ova hipoteza, koliko smo zaključili iz svih radova i studija o $\mathbf{S t}$, kasnije nije osporavana.

A. Badurina je, u monografiji Iluminirani rukopisi u Hrvatskoj, iz 1995., s povijesno-umjetničkog gledišta te na određen način proširujući Folnesicseve rezultate, prikazao rukopise (njih 265 od kojih su većina srednjovjekovni) koji se čuvaju u Hrvatskoj, a koji sadrže iluminacije i(li) inicijale. ${ }^{8}$ Rad možemo svrstati u znanstveno-popularni tip. U svakom slučaju Badurina nam potvrđuje činjenicu da su većina iluminiranih kodeksa (a gotovo svi poznati kodeksi u Hrvatskoj imaju neki inicijal ili iluminaciju) liturgijske knjige te je svjestan i njihove liturgijske važnosti. ${ }^{9}$ Ipak, ne ulazi ni u kakvu liturgijsku analizu bilo kojega rukopisa, već donosi kratki tehnički opis svakoga rukopisa kao i njegovu kratku povijest, posebno se referirajući na mjesto nastanka rukopisa. Neki podaci ipak nisu osvježeni novijim spoznajama pa su ponešto i zastarjeli. To vrijedi i za podatke o $\mathbf{S t}$, kojega Badurina još uvijek navodi kao Misal. Unatoč nepreciznosti-

5 Usp. V. Novak, Scriptura beneventana s osobitim obzirom na tip dalmatinske beneventane, Sveučilišna knjižnica, Zagreb, 1920.

6 Usp. V. Novak, Notae palaeographicae, Vjesnik Arheološkog muzeja u Zagrebu, 15/1 (1928.), 159-222.

7 Usp. B. Barrofio - Š. Marović, Il sacramentario rituale di Spalato e la tradizione eucologica latina, Ecclesia orans, 4 (1987.), 235-241.

8 Usp. A. Badurina, Illuminated manuscripts in Croatia, Kršćanska sadašnjost Institut za povijest umjetnosti, Zagreb, 1995.

9 Usp. A. Badurina, Illuminated manuscripts in Croatia, 8-10. 
ma i neažurnostima, ${ }^{10}$ Badurinina je monografija, zbog osnovnih podataka i osnovne literature ${ }^{11}$ o svakom kodeksu, još uvijek nezaobilazna pomoć u proučavanju srednjovjekovnih kodeksa u Hrvatskoj. U monografiji Riznica splitske katedrale, autori D. Deša, N. Gogala i S. Matijević St predstavljaju kao rukopisni i umjetnički "spomenik" srednjovjekovlja. Ne spominju nikakvu tipologiju knjige niti njezinu liturgijsku narav. ${ }^{12}$ Svrha ove kratke monografije je očito predstavljanje kulturnih dobara grada Splita široj publici. Kodeks St medu ostalim to i jest.

Najcjelovitiji rad o $\mathbf{S} \boldsymbol{t}$ dosada, u smislu preciznosti i točnosti podataka, napose o liturgijskim značajkama, jest onaj mo. Š. Marovića. Osamdesetih godina dvadesetog stoljeća tijekom istraživačkog rada na magisteriju ${ }^{13}$ iz gregorijanskog pjevanja, Marović je došao do mnogih spoznaja o $\mathbf{S t}$, od kojih je iz naše perspektive najvažnija precizirana tipologija: utvrdio je da je $\mathbf{S t}$ sakramentar, a ne kako se do tada već uvriježilo misal. Također je vrlo točno utvrdio da St sadrži više slojeva raznih povijesnih i liturgijskih utjecaja. Izuzev ove Marovićeve analize koja je također ograničena za potrebe muzikološkoga istraživanja, St nikada nije detaljnije analiziran s liturgijskoga aspekta. Marovićevi su rezultati s liturgijskoga stajališta zasigurno najpotpuniji dosada te su nam zato poslužili kao osnovno polazište u našem detaljnijem istraživanju liturgijskih specifičnosti kodeksa.

\subsection{Materijalni opis kodeksa}

\subsubsection{Korice ${ }^{14}$}

St je ukoričen u korice od bademova drva, koje su nekoć bile presvučene i kožom. Na njih su tijekom srednjeg vijeka postavlje-

10 Usp. Isto, 90-91. Zanimljivo je da Badurina nije konzultiaro rad Baroffia i Marovića u kojoj je točnije objašnjenja tipologija kodeksa St. Također navodi da mu je mjesto nastanka u sjevernoj Italiji ili sjevernoj Europi, dakle dosta neprecizno, unatoč tomu što je Marović već dvije godine ranije na hrvatskom jeziku objavio spoznaje o Sakramentaru i području na kojemu je nastao.

11 Usp. A. Badurina, Illuminated manuscripts in Croatia, 116-124.

12 Usp. D. Deša - N. Gogala - S. Matijević, Riznica splitske katedrale, Izdanje Muzeja grada Splita, Split, 1972., 153-154.

13 Usp. Š. Marović, Il Sacramentario del tesoro della cattedrale di Split (sig. 624) - Sacramentarium spalatense. Tesi di magistero, Pontificio Istituto di musica sacra, Roma, 1988. Dio rezultata istraživanja objavljeni su i obliku članka na hrvatskom i talijanskom jeziku. Na hrvatskom: S̆. Marović, Sakramentar riznice splitske katedrale, Bašćinski glasi (1993.), 51-98. Na talijanskom: vidi bilješku 6.

14 Zahvaljujemo povjesničarki umjetnosti Kristini Babić koja nam je pomogla u opisu korica kodeksa. 
ni srebrni okviri, pokrovi korica, ${ }^{15}$ remek-djelo reljefne tehnike, koji nam otkrivaju izuztenu sposobnost onoga tko ih je izradio. Na srebrnim pokrovima korica nalaze se i reljefi pozlaceenih figura. Prvi srebrni pokrov prikazuje Krista Kralja koji sjedi na nebeskom prijestolju u svečanoj odjeći. ${ }^{16}$ Drugim riječima prikazan je Krist Kralj - Pantokrator. Pored Kristove glave urezan je monogram IHS XPC - Iesous Christos. Lik Krista nalazi se unutar vijenca, "mandorle", uobičajene za srednji vijek, dočim oko mandorle imamo tetramorfne simbole evanđelista: na gornjoj lijevoj strani je orao (simbol sv. Ivana evanđelista), na gornjoj desnoj strani je anđeo (simbol sv. Mateja), na donjoj lijevoj strani je lav (simbol sv. Marka) i na donjoj desnoj strani je vol (simbol sv. Luke).

Druga srebrna korica prikazuje raspeće Kristovo s likovima Majke Kristove i sv. Ivana evanđelista, a nad poprečnom gredom križa stoje dva anđela. Izuzetno se ističe i titulus na križu, koji ne koristi uobičajeni ikonografski, tj. skraćeni prikaz natpisa (INRI), već je natpis u cijelosti napisan. ${ }^{17}$ Ispod križa prikazana je Adamova lubanja. Rubovi obaju srebrnih pokrova obrubljeni su prikazom vijenca od cvijeća i drugoga bilja. Nastanak ovih korica autori obično smještaju u 13. stoljeće, svakako nakon što bi kodeks došao do Splita. ${ }^{18}$

\subsubsection{Dimenzije kodeksa i impostacija listova}

Dimenzije listova su 150 × $230 \mathrm{~mm}$. Prostor za pisanje na listu uređen je u jednom stupcu dimenzija 100 x $165 \mathrm{~mm}$ u 18 redaka. Prva dva i posljednja dva lista ne sadrže nikakav tekst pa ni označene retke za pisanje, nego se radi o nešto kasnijim dodacima koji učvršćuju uvez. Formula kojom se opisuju dimenzije kodeksa prema kodikološkoj metodologiji opisuje retke i margine lista poput jednadžbe i uvijek se odnosi na recto stranu lista. Prvi dio je širina lista u kojoj se navode (obično u milimetrima sa znakom zbrajanja među podacima) širina unutarnje margine, širina stupca teksta pa onda širina vanjske margine. Nakon podataka o širini lista dolazi

15 Marović se poziva na Novakova istraživanja koji na temelju srebrnih korica sakramentara i njihove sličnosti sa koricama Evanđelistara iz 12. stoljeća, pretpostavlja da su nastale u Italiji pa bi posljedično i sam kodeks bio donošen iz Italije, što se uklapalo u tradicionalnu hipotezu prema kojoj ga je u Split donio nadbiskup Bernardo krajem 12. ili početkom 13. stoljeća. Usp. Marović, Sakramentar riznice splitske katedrale, 66.

16 Usp. D. Deša - N. Gogala - S. Matijević, Riznica Splitske katedrale, 154.

17 Iesus Nazarenus Rex Iud $\langle a\rangle$ eorum. Ime Isus - Iesus, napisano je skraćeno kako je u ikonografiji toga vremena uobičajeno: IHS. Usp. Deša - Gogala - Matijević, Riznica Splitske katedrale, 154.

18 Usp. V. Novak, Notae palaeographicae, 159-187. 
matematički znak množenja X, te se navode podaci o visini (duljini) lista na isti način kao i za širinu - samo što su umjesto unutarnje i vanjske marginu, sada donja i gornja margina. Dakle u dijelu formule koji opisuje visinu lista navodi se "visina" (ili širina) gornje margine, visina stupca teksta, te visina donje margine. U zagradi pored visine stupca teksta obično se navode širina pojedinoga retka i broj redaka u stupcu. Prema tome formula dimenzija i impostacije stranice jest sljedeća:

$$
20+90+40 \times 10+160(\text { R. } 8.8,18)+60
$$

Tekst je uglavnom dobro sačuvan i lako čitljiv. Na pojedinim listovima imamo minijature, iluminacije, kao i inicijale. Pojedini inicijali su detaljnije ukrašeni, ${ }^{19}$ ali većina je inicijala jednostavno ukrašena: izmjenjuju se crvena i plava tinta u euhološkim formulama u cijelom kodeksu.

\subsubsection{Paginacija}

Svi listovi označeni su arapskim brojkama, a upisani su olovkom $\mathrm{u}$ gornji desni kut na recto stranu lista $\mathrm{u}$ novije vrijeme. Već smo spomenuli da je materijal od kojega su izrađeni listovi pergamena, izuzetno dobro očuvana, osim nekoliko prvih i posljednjih listova kodeksa koji su oštećeni, odnosno istrošeni, na kojima je tekst izblijedio od uporabe. To nije ništa čudno jer u mnogim srednjovjekovnim kodeksima postoje slična oštećenja. Osim izblijedjelog teksta moramo spomenuti i ponešto oštećenu, ali prekrasnu minijaturu koja prikazuje raspeće na listu $f$. $3 r$ u $\mathbf{S t}$.

Složenost i heterogenost kodeksa odaju nam njegovu, nije pretjerano kazati, uzbudljivu prošlost. Kodeks je bio često korišten: naime $\mathrm{u}$ trenutnom stanju pri prelistavanju listova još je Marović uočio kako liturgijski formulari na nekim listovima nisu poredani očekivanim redoslijedom. To je rezultat čestoga korištenja kodeksa koji se $\mathrm{u}$ jednom trenutku u povijesti, kada vjerojatno više nije bio korišten, jednostavno pokidao, u smislu da su listovi poispadali, a kasnije su jednostavno skupljeni i sastavljeni onako kako su zatečeni. ${ }^{20}$ Arhivar je kasnije ne vodeći računa o ispravnom redoslijedu formula samo olovkom upisao brojeve stranica i to je stanje ostalo do danas. Tu je načinio i grešku pri upisivanju broja listova. Nakon lista 113, upisan je ponovno list 112 te nakon nje-

19 Velike inicijale koji već pokazuju zavidnu vještinu ukrašavanja imamo na ff. 4ri 4v.

20 Da je $\mathbf{S} \boldsymbol{t}$ bio još uvijek korišten u vrijeme kada se ponovno dogodio uvez u aktualno stanje, vjerojatno bi ispremiješani listovi bili složeni ispravnim redoslijedom. 
ga slijedi list 114. Stoga imamo dva lista označena sa brojem 112. Prema suvremenim kodikološkim metodama ovakve se greške ukoliko ih ima u kodeksima redovito rješavaju na način da se drugi list označi jednostavno $112 \mathrm{bis}^{21}{ }^{21}$ To je metoda koju smo i mi koristili kako bismo pojednostavnili praćenje liturgijske strukture.

\subsubsection{Osnovne paleografske značajke}

Najveći dio teksta u St pisan je karolinškom minuskulom. Naknadni interventi, odnosno kasnije umetnuti listovi pisani su goticom. Pri kraju kodeksa nalaze se dva starija lista pisana dalmatinskom beneventanom. ${ }^{22}$ Ovi su listovi prilično stariji od ostatka kodeksa. Listovi koji sadrže goticu očito su umetnuti s namjerom, kao kasnija dopuna u razvoju određenih liturgijskih obreda. Vrlo jasan dokaz u prilog tome jest impostacija tih listova koji su u dimenzijama jednaki kao i oni pisani karolinom. Listovi pisani beneventanom se razlikuju. Čak i karolinška minuskula pokazuje stilske varijacije - ne radi se o različitim epohama pisanja, već prije o različitim pisarima na tom glavnom dijelu kodeksa. ${ }^{23}$

\section{LITURGIJSKI SADRŽAJ}

Prva dva lista umetnuti su kao naknadno učvršćenje, nakon primarnoga uveza te nisu uopće bili predviđeni za pisanje. Pokazatelj toga jest i njihova debljina: $u$ odnosu na ostatak listova $u$ kodeksu ta su dva lista nešto deblja. To nam u konačnici svjedoči da je kodeks još za vrijeme uporabe u srednjovjekovnom razdoblju bio obnavljan. Gdje se pretpostavljena obnova dogodila - u Splitu

21 Kodikologija ne označuje stranice u današnjem smislu, već listove. Svaki list ima prednju (recto) i stražnju (verso) stranu. U označavanju broja listova stoga se vodi računa o toj metodi pa se listovi označuju brojem i oznakom $r$ ili $v$ ovisno od toga radi li se već o prednjoj ili stražnjoj strani lista. Npr. f. 5 r označuje 5 list (folium) i njegovu prednju stranu (recto). U St imamo grešku pri upisivanju broja listova. Nakon lista 113, upisan je ponovno list 112 te nakon njega slijedi list 114 . Stoga imamo dva lista označena sa brojem 112. Š. Marović je doslovno slijedio ovakvu paginaciju, s tim da je list na kojemu je greška, odnosno drugi sa brojem 112, označio sa f 114 (112), te je tako nastavio. Usp. Š. Marović, Il Sacramentario del tesoro della cattedrale di Split, 15-30.

22 Usp. V. Novak, Notae palaeographicae, 159. Radi se o jedinstvenoj dvolisnici, monionu, dva lista koji su iz nekoga mnogo starijega sakramentara. Držimo da ih je netko od arhivara, želeići ih sačuvati, još u srednjem vijeku umetnuo unutar već postojeće knjige koja se u to doba koristila u katedrali.

23 Npr. na f. 21r horizontalna crtica iznad slova $p$ je ponešto zakrivljena, valovita, dok na f. $133 \mathrm{r}$ je potpuno ravna. 
ili negdje gdje je kodeks bio prije nego je stigao do Splita - nemamo nikakvih podataka, ali za pretpostaviti je da je bila u Splitu. Prvi list na kojemu je nešto pisano, odnosno bolje reći slikano jest treći (f. 3r). Na f. $3 \mathrm{r}^{24}$ nalazimo prekrasnu minijaturu koja prikazuje Kristovo raspeće. Taj prikaz jako podsjeća na onaj sa stražnje srebrne korice kodeksa. Zanimljiv je i znakovit izbor boja u minijaturi. Nebo je zlatno, dok je zemlja (Kalvarija) u plavoj boji!

Liturgijska struktura sličnih kodeksa, ali i tekstualni sadržaj St, upućuju da bi nakon f. 3r, dakle na f. 3v, trebao početi tekst koji sadrži misni kanon. List f. 3v ima vlastitu impostaciju različitu od osnovne prikazane ranije. Također unatoč izblijedjelom tekstu razlučuju se jasno i različiti tipovi pisma i različita veličina slova: pri vrhu stranice su manja slova, dok su dalje otprilike dvostruko veća. Stoga možemo zaključiti kako je i f. 3 kasniji dodatak - moguće da je stavljen kao zamjena za potrošene i neupotrebljive listove. ${ }^{25}$

\subsection{Liturgijska struktura}

Polazeći u svome istraživanju od slijeda liturgijskih formula kako ih je zatekao u aktualnom staju kodeksa te ih uspoređujući s drugim srednjovjekovnim izvorima Marović je pokazao očitu diskrepanciju u rasporedu liturgijskih formula u St. Kasnije je usporednom analizom s obrascima iz drugih značajnih sakramentara došao do izvornoga slijeda. ${ }^{26}$

Mi donosimo trenutno zatečeno stanje, s ponešto prilagođenim naslovima obrazaca i detaljnijim ažuriranjem, u odnosu na Marovićev prikaz, zahvaljujući suvremenoj liturgijskoj metodologiji i metodama za kritiku liturgijskog teksta.

24 Na gornjem dijelu toga lista nalazi se redak izblijedjeloga teksta koji je gotovo nečitljiv. Ostali dio stranice sadrži minijaturu na kojoj je prikazano raspeće. Usp. A. Badurina, Illuminated manuscripts in Croatia, 91.

25 Tekstualna kritika u budućnosti bi trebala pokazati o kojemu tekstu je riječ. Prema rasporedu i strukturi sakramentara iz toga doba vjerojatno f. 3v sadrži misni kanon. Kako su se misni kanoni unutar kodeksa najčešće koristili, nije neobično što bi se i nakon nekoga vremena istrošili pogotovo neadekvatnim rukovanjem. Stoga je logično da je možda i bio zamijenjen novim listom s novim misnim kanonom. Stil pisma kako se može razaznati s f. 3v, kao i kodikološka struktura prema kojoj su ff. 3 i 4 jedna dvolisnica, monion, te da nisu dio quaterniona, koji su uobičajena forma, i u St, pokazuje da je ova hipoteza izgledna.

26 Usp. Š. Marović, Sakramentar riznice splitske katedrale, 56-57. Diskrepancija je vidljiva već iz samih naslova formulara bez detaljnije analize teksta. Npr. na f. 20v imamo obrazac Feria VI, nakon kojega na sljedećem listu imamo obrazac Feria II. Dakle nakon petka (Feria VI) imamo ponedjeljak (Feria II). 


\section{SACRAMENTARIUM SPALATENSE}

Liturgijska shema

\begin{tabular}{|l|l|}
\hline ff $3 r-9 v$ & Ordo missae \\
\hline f $10 r$ & In vigilia Nativitatis Domini \\
\hline & In galli cantu \\
\hline f $11 \mathrm{r}$ & In mane \\
\hline f $11 \mathrm{v}$ & In die \\
\hline f $12 \mathrm{v}$ & Dominica I post nativitatem Domini \\
\hline & De sancta Maria \\
\hline f $13 \mathrm{r}$ & In octava Domini \\
\hline f $13 \mathrm{v}$ & Vigilia Epyphaninae \\
\hline f $14 \mathrm{r}$ & In die \\
\hline f $14 \mathrm{v}$ & Dominica I post Epyphaniae \\
\hline f $15 \mathrm{r}$ & In octava Epyphaniae \\
\hline f $15 \mathrm{v}$ & Dominica II \\
\hline & Dominica III \\
\hline f $16 \mathrm{r}$ & Dominica IIII \\
\hline f $16 \mathrm{v}$ & Dominica V \\
\hline & Dominica VI \\
\hline f $17 \mathrm{r}$ & Dominica in LXX \\
\hline & Dominica in LX \\
\hline f $17 \mathrm{v}$ & Dominica in L \\
\hline f $18 \mathrm{r}$ & Benedictio cyneris. Feria IIII \\
\hline f $19 \mathrm{v}$ & Ad missam \\
\hline f $20 \mathrm{r}$ & Feria V \\
\hline f $20 \mathrm{v}$ & Feria VI \\
\hline f $21 \mathrm{r}$ & Feria II \\
\hline & Feria III \\
\hline f $21 \mathrm{v}$ & Feria IIII \\
\hline f $22 \mathrm{r}$ & Feria V \\
\hline f $22 \mathrm{v}$ & Feria VI \\
\hline & Sabbato \\
\hline & Feria V \\
\hline
\end{tabular}




\begin{tabular}{|l|l|}
\hline f $23 \mathrm{v}$ & Feria VI \\
\hline f $24 \mathrm{r}$ & Sabbato \\
\hline f $24 \mathrm{v}$ & Dominica in XL \\
\hline f $25 \mathrm{v}$ & Dominica II \\
\hline f $26 \mathrm{r}$ & Feria II \\
\hline & Feria III \\
\hline f $26 \mathrm{v}$ & Feria IIII \\
\hline f $27 \mathrm{r}$ & Sabbato \\
\hline & Dominica III \\
\hline f $27 \mathrm{v}$ & Feria II \\
\hline f $28 \mathrm{r}$ & Dominica in ramis palmarum \\
\hline f $29 \mathrm{r}$ & Lectio libri Exodi \\
\hline f $30 \mathrm{v}$ & Sequentina sancti Evangelii secundum Matthaeum \\
\hline f $31 \mathrm{r}$ & Benedictio olivarum ${ }^{27}$ \\
\hline f $32 \mathrm{v}$ & Benedictio palmarum \\
\hline f $33 \mathrm{v}$ & Sabbato \\
\hline f $34 \mathrm{v}$ & Feria II \\
\hline & Feria III \\
\hline f $35 \mathrm{r}$ & Feria IIII \\
\hline f $36 \mathrm{r}$ & Feria $V$ \\
\hline f $37 \mathrm{r}$ & Feria VI \\
\hline f $40 \mathrm{r}$ & Feria IIII \\
\hline f $40 \mathrm{v}$ & Feria V \\
\hline f $41 \mathrm{r}$ & Feria III \\
\hline & Feria IIII \\
\hline f $41 \mathrm{v}$ & Feria V \\
\hline f $42 \mathrm{r}$ & Feria VI \\
\hline f $42 \mathrm{v}$ & Sabbato \\
\hline f $43 \mathrm{r}$ & Dominica IIII \\
\hline f $43 \mathrm{v}$ & Feria II \\
\hline & Feria III \\
\hline & \\
\hline
\end{tabular}

27 Marović u prikaz liturgijske strukture nije uvrstio ovaj blagoslov. Usp. Š. Marović, Sakramentar riznice splitske katedrale, 70. 


\begin{tabular}{|c|c|}
\hline f $44 r$ & Dominica V \\
\hline & Feria II \\
\hline $\mathrm{f} 44 \mathrm{v}$ & Feria III \\
\hline f $45 r$ & Feria IIII \\
\hline$f 45 v$ & Feria V \\
\hline f 46r & Feria VI \\
\hline$f 46 v$ & Sabbato \\
\hline $\mathrm{f} 47 \mathrm{r}$ & Feria VI \\
\hline$f 47 v$ & Sabbato \\
\hline f $51 \mathrm{r}$ & Ad missam \\
\hline$f 52 r$ & In die \\
\hline$f 53 r$ & Feria II \\
\hline f $54 \mathrm{r}$ & Feria III \\
\hline f $54 v$ & Feria IIII \\
\hline$f 55 r$ & Feria V \\
\hline f $56 r$ & Feria VI \\
\hline$f 56 v$ & Sabbato \\
\hline f $57 \mathrm{r}$ & Dominica post alba \\
\hline \multirow[t]{2}{*}{ f $57 \mathrm{v}$} & Dominica II \\
\hline & Dominica III \\
\hline $\mathrm{f} 58 \mathrm{r}$ & Dominica IIII \\
\hline \multirow[t]{2}{*}{ f $58 v$} & Dominica V \\
\hline & Feria II \\
\hline f $59 r$ & Vigilia Ascensionis Domini \\
\hline$f 59 v$ & In die \\
\hline f $60 r$ & Dominica I post Ascensionem \\
\hline f $60 v$ & Sabbato sancto Pentecosten \\
\hline$f 62 v$ & In die \\
\hline \multirow[t]{2}{*}{ f 63v } & Feria II \\
\hline & Feria III \\
\hline f $64 r$ & Feria IIII \\
\hline \multirow[t]{2}{*}{$\mathrm{f} 64 \mathrm{v}$} & $\mathrm{V}$ feria \\
\hline & Feria VI \\
\hline f $65 r$ & Sabbato \\
\hline
\end{tabular}




\begin{tabular}{|l|l|}
\hline f 66r & De Sanctissima Trinitate \\
\hline f 67r & Dominica I post Pentecosten \\
\hline & Dominica II \\
\hline f 67v & Dominica III \\
\hline f 68r & Dominica IV \\
\hline & Dominica V \\
\hline f 68v & Dominica VI \\
\hline f 69r & Dominica VII \\
\hline & Dominica VIII \\
\hline f 69v & Dominica VIIII \\
\hline f 70r & Dominica X \\
\hline f 70v & Dominica XI \\
\hline & Dominica XII \\
\hline f 71r & Dominica XIII \\
\hline f 71v & Dominica XII II 7 \\
\hline & Dominica XV \\
\hline f 72r & Dominica XVI \\
\hline f 72v & Dominica XVII \\
\hline & Feria IIII \\
\hline f 73r & Feria VI \\
\hline f 73v & Sabbato \\
\hline f 74r & Dominica XVIIII \\
\hline f 74v & Dominica XX \\
\hline & Dominica XXI \\
\hline f 75r & Dominica XXII \\
\hline & Dominica XXIII \\
\hline f 75v & Dominica XXIIII \\
\hline f 76r & Dominica I de Adventu Domini \\
\hline f 76r & Dominica II \\
\hline f 77r & Dominica III \\
\hline & Feria IIII \\
\hline f 77v & Feria VI \\
\hline f 78r & Sabbato \\
\hline f 79r & Dominica IIII \\
\hline
\end{tabular}




\begin{tabular}{|l|l|}
\hline & De Omnibus sanctis \\
\hline f 80r & In natale sancti Stephani protomartyris \\
\hline f 80v & Sancti Iohannis Evangelistae \\
\hline f 81r & In natale sanctorum Innocentum \\
\hline & Silvestri papae \\
\hline f 81v & Hylarii atque Remigii \\
\hline f 82r & Felicis inpicis \\
\hline & Mauri abbatis \\
\hline f 82v & Marcelli papae et martyris \\
\hline f 83r & Priscae martyris \\
\hline & Fabiani et Sebastiani matyrum \\
\hline f 84r & Agnetis martyris \\
\hline f 84v & Vincentii mris \\
\hline & Conversione sancti Pauli \\
\hline f 85r & Pr<a>eiecti Martyris \\
\hline f 85v & Agnetis scdo \\
\hline f 86r & Benedictio cereorum \\
\hline f 90r & In purificatione sanctae Mariae \\
\hline f 91v & In die \\
\hline f 92r & Agath<a>e martyris \\
\hline f 92v & Scolasticae virginis \\
\hline f 93r & Valentini martyris \\
\hline f 93v & Eodem die-Sanctorum Valentini, Vitali, Feliculae, Zenonis \\
\hline f 94r & Cathedra sancti Petri \\
\hline & Mathiae apostoli \\
\hline f 94v & Albini confessoris \\
\hline f 95r & Perpetuae et Felicitatis \\
\hline f 95v & Gregorii papae (depostitio) \\
\hline & Benedicti abbatis \\
\hline f 96r & In annuntiatione sanctae Mariae \\
\hline f 97r & Ambrosii confessoris \\
\hline & Tyburcii, Valeriani, Maximi \\
\hline f 97v & Georgii martyris \\
\hline
\end{tabular}




\begin{tabular}{|c|c|}
\hline f $98 \mathrm{r}$ & Marci evangelistae \\
\hline \multirow[t]{2}{*}{ f $98 v$} & Vitalis martyris \\
\hline & Phylippi et Iacobi \\
\hline f $99 r$ & In inventione Sanctae crucis \\
\hline f $100 r$ & Eodem die - Alexandri, Eventii et Theoduli \\
\hline \multirow[t]{2}{*}{ f $100 v$} & Iohannis Flagelatio - Sancti Iohannis ante Portam latinam \\
\hline & Gordiani et Epymachi \\
\hline \multirow[t]{2}{*}{ f $101 \mathrm{r}$} & Sancti Pancratii martyris \\
\hline & Sanctorum Nerei et Achillei \\
\hline f $101 v$ & Sancta Mariae ad Martyres \\
\hline f $102 r$ & Urbani papae et martyris \\
\hline \multirow[t]{2}{*}{ f $102 v$} & Nichomedi martyris \\
\hline & Marcellini et Petri \\
\hline f $103 r$ & Primi et Feliciani \\
\hline f $103 v$ & Sancti Barnabae apostoli \\
\hline \multirow[t]{2}{*}{ f $104 r$} & Basilidis, Cyrini, Naboris et Nazarii martyrum \\
\hline & Marci et Marcelliani \\
\hline f $104 v$ & Gervasii et Prothasii martyrum \\
\hline f $105 r$ & Vigilia sancti Iohannis Baptistae \\
\hline f $106 r$ & Iohannis et Pauli martyrum \\
\hline f $106 \mathrm{v}$ & Vigilia apostoli Petri et Pauli \\
\hline f $107 \mathrm{r}$ & Ipso die Leonis papae (intra messa festa nel Petri et Pauli!!!) \\
\hline f $108 \mathrm{r}$ & Commemoratio sancti Pauli \\
\hline f $108 v$ & Processi et Martiniani martyrum \\
\hline \multirow[t]{2}{*}{ f $109 r$} & Translatione s. Martini \\
\hline & In octava apostolorum \\
\hline f $109 v$ & VII Fer missa (Septem fratrem sanctorum) \\
\hline \multirow[t]{2}{*}{ f $110 r$} & Translatio s. Benedicti \\
\hline & $\begin{array}{l}\text { In festivitate s. Ierusalem (Pro custodia monasterii et } \\
\text { habiattorum eius) }\end{array}$ \\
\hline \multirow[t]{2}{*}{$\mathrm{f} 110 \mathrm{v}$} & Praxedis virginis \\
\hline & Mariae Magdalenae \\
\hline f $111 \mathrm{r}$ & Apollinaris Martyris \\
\hline
\end{tabular}




\begin{tabular}{|l|l|}
\hline f 11 v & Vigilia sancti Iacobi \\
\hline f 112r & In die \\
\hline f 112v & Christophori et Cucuphati \\
\hline f 113r & Felicis, Simplicii, Faustini et Beatrici \\
\hline f 112bis r & Sanctorum Abdon et Sennen \\
\hline & Germani confessoris atque pontificis \\
\hline f 114r & Ad vincula Sancti Petri \\
\hline & Ipso die Sanctoruum Machabeorum \\
\hline f 114v & Stephani papae et martyris \\
\hline f 115r & Inventio sancti Stephani \\
\hline & Syxti, Felicissimi, Agapiti \\
\hline f 115v & Benedictio uvae \\
\hline f 116r & Donati episcopi et martyris \\
\hline f 116v & Cyriaci cum sociis suis \\
\hline & Vigilia sancti Laurentii \\
\hline f 117r & In mane \\
\hline f 117v & In die \\
\hline & Tyburcii martyris \\
\hline f 118r & $<$ H>ypoliti martyris \\
\hline f 118v & Eusebii confessoris \\
\hline & Vigilia assumptionis Sanctae Mariae \\
\hline f 119r & In die \\
\hline f 120r & In octava sancti Laurentii \\
\hline & Agapiti martyris \\
\hline f 120v & Tymothei et Symphoriani \\
\hline f 121r & Vigilia sancti Bartholomei \\
\hline f 121v & In die \\
\hline & Hermetis martyris \\
\hline f 122r & Augustini confessoris \\
\hline f 122v & $<$ Decollatio Sancti> Iohannis Baptistae \\
\hline f 123r & Sabin<a>e virginis et martyris \\
\hline f 123v & Sanctorum Felicis et Adaucti martyres \\
\hline & In Nativitate Sanctae Mariae \\
\hline
\end{tabular}




\begin{tabular}{|l|l|}
\hline f 124v & $<$ H>adriani martyris \\
\hline & Gorgonii martyris \\
\hline f 125r & Proti et Iacincti \\
\hline & In exaltatione sanctae crucis \\
\hline f 126r & Sanctorum Cornelii et Cipriani \\
\hline & Sancti Nichomedis martyris \\
\hline f 126v & S. Eufemie virginis et sanctorum Luci<a $>$ e et Geminiani \\
\hline f 127r & In vigilia sancti Mathei apostolis \\
\hline f 127v & Sancti Mathei \\
\hline f 128r & Natale sanctorvm Mavricii Exsvperii Candidi et sociis \\
\hline f 128v & Cosm<a>e et Damiani \\
\hline & S. Michael Archangeli \\
\hline f 129r & Iheronimi pbri (!) \\
\hline f 129v & Vedasti, Remigii, Germani confessoris \\
\hline f 130r & Leodegarii martyris \\
\hline f 130v & Marchi, episcopi et confessoris \\
\hline f 131r & Dionisii confessoris \\
\hline f 131v & Calixti papae \\
\hline & Lucae evangelistae \\
\hline f 132r & Crispini et Crispiniani \\
\hline f 132v & Vigilia apostoli Simoni et Iudae \\
\hline & In die \\
\hline f 133v & Vigilia omnium sanctorum \\
\hline & In die \\
\hline f 134v & Eodem die Cesarii martyris \\
\hline & IIII coronatorum \\
\hline f 135r & Theodouli martyris \\
\hline f 135v & Mennae Martyris \\
\hline & Eodem die Martini confessoris \\
\hline f 136r & C<a>eciliae virginis \\
\hline & Clementis martyris \\
\hline f 136v & Felicitatis martyris \\
\hline f 137r & C<h>risogoni martyris \\
\hline & \\
\hline
\end{tabular}




\begin{tabular}{|l|l|}
\hline & Saturnini martyris \\
\hline f 137v & Vigilia sancti Andreae \\
\hline f 138r & In die \\
\hline & Beati Nicholai conf. \\
\hline f 138v & Octava sancti Andreae \\
\hline f 139r & Eulaliae martyris \\
\hline & Damasi papae \\
\hline f 139v & Luciae virginis \\
\hline f 140r & In festivitate sancti Lazari officium \\
\hline f 140v & 「Vigilia Thomae apostoli \\
\hline f 141r & In die \\
\hline & In natale sanctorum apostolorum \\
\hline f 141v & Unius martyris \\
\hline f 142v & Plurimorum martyrum \\
\hline f 143r & In natale unius pontificis \\
\hline f 143v & In natale unius confessoris \\
\hline f 144r & Plurimorum confessorum \\
\hline f 144v & In natale unius virginis et martyris \\
\hline & In deédiùcatione templi \\
\hline f 145v & Alia missa \\
\hline f 146v & De sancta Trinitate \\
\hline & Lectio ad Corinthios \\
\hline & Secundum Iohannem \\
\hline f 147r & Pr<a>efatio \\
\hline f 147v & In honore Sanctae Mariae \\
\hline & Lectio I. Sapientiae \\
\hline f 148r & Secundum Lucam \\
\hline f 148v & De Sancta Cruce \\
\hline & Ad Philipenses \\
\hline f 149r & Secundum Matthaeum \\
\hline f 149v & In honore sanctorum angelorum \\
\hline & Lectio libri Apocalipsis Iohannis apostoli \\
\hline & Secundum Matthaeum \\
\hline & \\
\hline &
\end{tabular}




\begin{tabular}{|l|l|}
\hline f 150r & De omnibus sanctis \\
\hline f 150v & Ad gratiam Sancti Spiritus postulanda \\
\hline f 15lr & De sancta sapientia \\
\hline f 15lv & Ad poscendum donum karitatis \\
\hline & Pro familiaribus \\
\hline f 152r & Lectio Ieremiae prophetae \\
\hline & Secundum Lucam \\
\hline f 153r & Missa pro semetipso \\
\hline f 153v & Alia missa \\
\hline f 154r & Alia missa \\
\hline f 154v & Alia missa \\
\hline f 155r & Pro temptatione inimicorum invisibilium \\
\hline f 155v & Contra temptationes carnis \\
\hline f 156r & Missa pro episcopo \\
\hline f 156v & Pro petitione lacrimarum \\
\hline f 157r & Pro rege \\
\hline f 157v & Pro abbate et congregatio \\
\hline & Pro amico vivente \\
\hline f 158r & Alia missa \\
\hline f 158v & Pro familiaribus \\
\hline f 159v & Pro concordia fratrum \\
\hline f 160r & Pro pace \\
\hline f 160v & Contra paganos \\
\hline f 161v & Pro peccatis \\
\hline f 162r & Pro quacumque tribulatione \\
\hline f 162v & Ad pluviam postulandam \\
\hline & Pro serenitate \\
\hline f 163r & Pro iter agentibus missa \\
\hline f 164r & Pro infirmo \\
\hline f 164v & Missa generalis \\
\hline f 165r & Alia missa \\
\hline f 168v & Missa pro eo qui proximus est morti \\
\hline f $169 r$ & Incipit ordo ad sponsandam mulierem \\
\hline
\end{tabular}




\begin{tabular}{|l|l|}
\hline f $172 v$ & Incipit ordo ad cathecuminum faciendum \\
\hline f $173 v$ & Benedictio salis \\
\hline f $178 v$ & Benedictio fontis \\
\hline f $183 r$ & Incipit ordo ad visitandum infirmorum \\
\hline f 192r & Commendatio animae - Liturgia funeralis \\
\hline f 200r & Missa pro patre et matre \\
\hline f 200v & Pro benefactoribus nostris defunctis \\
\hline f. $202 r$ & (Missa in tribulatione) \\
\hline f. 202 v & Sancti Francisci Confessoris \\
\hline & Sancti Dominici \\
\hline f. $203 r$ & Incognita \\
\hline f. $203 v$ & (Missa pro navigantibus) \\
\hline f $204 r$ & In sancti Stephani regis \\
\hline f $205 r$ & In die depositionis missa \\
\hline f $206 r$ & Missa pro defuncto sacerdote vel episcopo \\
\hline f $207 r$ & Alia missa \\
\hline f $208 r$ & Missa pro episcopo vel sacerdote \\
\hline f $209 v$ & Pro congregationem fratrum et sororum \\
\hline f $210 r$ & Pro defunctis \\
\hline f $210 v$ & Missa pro femina defuncta \\
\hline f 211 r & In die depositionis missa \\
\hline & In die anniversarii \\
\hline f $211 v$ & Alia missa \\
\hline f $212 r$ & Missa pro defuncto \\
\hline f $212 v$ & Pro femina defuncta \\
\hline f $213 r$ & Pro desiderante p<a $>$ enitentiam \\
\hline f $213 v$ & Pro his qui in cimiterio requiescant \\
\hline f $214 r$ & Pro cunctis fidelibus defunctis \\
\hline f $214 v$ & Exorcismus salis \\
\hline f $215 r$ & Exorcismus aquae \\
\hline f $216 r$ & Benedictio salis et aquae \\
\hline & \\
\hline
\end{tabular}


Pažljivije promatranje slijeda formula od f. 20r do f. $47 \mathrm{v}$ pokazuje rečene nedosljednosti uočene već od Š. Marovića: ${ }^{28}$ više je nego očit pogrešan slijed dana u tjednu. Dakle, izvorni slijed listova i sveščića u ovome pogrješno uređenom dijelu kodeksa, a time i liturgijska struktura jest sljedeća:

\begin{tabular}{|l|l|}
\hline f $20 v$ & Feria VI \\
\hline f $24 r$ & Sabbato \\
\hline f $24 v$ & Dominica in XL \\
\hline f $21 r$ & Feria II \\
\hline & Feria III \\
\hline f $21 v$ & Feria IIII \\
\hline f $22 r$ & Feria V \\
\hline f $22 v$ & Feria VI \\
\hline & Sabbato \\
\hline f $25 v$ & Dominica II \\
\hline f $26 r$ & Feria II \\
\hline & Feria III \\
\hline f $26 v$ & Feria IIII \\
\hline f $23 r$ & Feria V \\
\hline f $23 v$ & Feria VI \\
\hline f $27 r$ & Sabbato \\
\hline & Dominica III \\
\hline f $27 v$ & Feria II \\
\hline f $41 \mathrm{r}$ & Feria III \\
\hline & Feria IIII \\
\hline f $41 v$ & Feria V \\
\hline f $42 r$ & Feria VI \\
\hline f $42 v$ & Sabbato \\
\hline f $43 r$ & Dominica IIII \\
\hline f $43 v$ & \\
\hline & Feria II \\
\hline
\end{tabular}

28 Usp. Š. Marović, Sakramentar riznice splitske katedrale, 69-79. 


\begin{tabular}{|l|l|}
\hline f $40 \mathrm{r}$ & Feria IIII \\
\hline f $40 \mathrm{v}$ & Feria V \\
\hline f $47 \mathrm{r}$ & Feria VI \\
\hline f $47 \mathrm{v}$ & Sabbato \\
\hline f $44 \mathrm{r}$ & Dominica V \\
\hline & Feria II \\
\hline f $44 \mathrm{v}$ & Feria III \\
\hline f $45 \mathrm{r}$ & Feria IIII \\
\hline f $45 \mathrm{v}$ & Feria V \\
\hline f $46 \mathrm{r}$ & Feria VI \\
\hline f $46 \mathrm{v}$ & Sabbato \\
\hline f $28 \mathrm{r}$ & Dominica in ramis palmarum \\
\hline f $31 \mathrm{r}$ & Benedictio olivarum \\
\hline f $32 \mathrm{v}$ & Benedictio palmarum \\
\hline f $34 \mathrm{v}$ & Feria II \\
\hline & Feria III \\
\hline f 35r & Feria IIII \\
\hline f $36 \mathrm{r}$ & Feria V \\
\hline f $37 \mathrm{r}$ & Feria VI \\
\hline f $33 \mathrm{v}$ & Sabbato \\
\hline & \\
\hline
\end{tabular}

Iako nije bio u mogućnosti koristiti metode suvremene kodikologije Marović je ipak uz dosta napora uspješno rekonstruirao izvoran slijed obrazaca. ${ }^{29}$ Uspoređujući tekstove misnih formula u obrascima možemo potvrditi Marovićeve rezultate, što potvrđuju i rezultati naše kodikološke analize. Zahvaljujući tim spoznajama zaključujemo kako se od Marovića ponovno uspostavljen redoslijed listova i sveščića savršeno uklapa u izvorni liturgijski slijed formula zasvjedočen u srednjovjekovnim liturgijskim izvorima. Ipak do danas kodeks nije restauriran na način da se uspostavi izvorni slijed listova te da se prilagodi kodikološka numeracija. ${ }^{30}$

29 Usp. Š. Marović, Sakramentar riznice splitske katedrale, 69-79.

30 U tu svrhu prijedlog čuvarima Katedralne riznice kao i konzervatorima jest da se kodeks čim prije restaurira i ponovno uveže u najizvornije moguće stanje, vodeći dakako računa i o kasnijim umetcima. 


\subsection{Tipološki dijelovi}

Daljnja značajka St, izuzmemo li dodatke koji su ponešto poremetili izvornu strukturu, jesu jasno razlučeni tipološki dijelovi, odnosno, temporal, sanktoral, zajedničke te obredne mise.

Na ovoj osnovi obrasce u sakramentaru možemo općenito razvrstati na sljedeći način:

\begin{tabular}{|l|l|}
\hline ff. $3 \mathrm{r}-79 \mathrm{v}$ & Temporal \\
\hline ff. $80 \mathrm{r}-141 \mathrm{r}$ & Sanktoral $^{31}$ \\
\hline ff. $141 \mathrm{v}-214 \mathrm{r}$ & $\begin{array}{l}\text { Zajedničke i obredne mise }- \text { communia et } \\
\text { missae rituales }\end{array}$ \\
\hline ff. $214 \mathrm{v}-216 \mathrm{r}$ & Egzorcizmi \\
\hline
\end{tabular}

Ovdje nismo uzeli u obzir kasnije dodane listove pri kraju kodeksa. Rani sakramentari, pa čak i dobar dio sakramentarâ $\mathrm{u}$ visokom srednjem vijeku, još uvijek ima isprepletene tipološke sadržaje: iako još od Gelazijevskoga sakramentara postoji razlikovanje većih dijelova tzv. temporala i sanktorala, ${ }^{32}$ ipak se još uvijek neka svetačka slavlja nalaze inkorporirana u temporal, dakle u Gospodnja slavlja i nedjelje tijekom liturgijske godine. Uobičajeni primjer su blagdani sv. Stjepana Prvomučenika i sv. Ivana apostola i evanđelista. Nerijetko ih u srednjovjekovnim liturgijskim knjigama nalazimo unutar Božićnoga temporala, odmah, što je i logično nakon Božića. U St ne nalaze se odmah nakon Božića, nego tek na tematski novome dijelu kodeksa na f. 80r i f. 80v. Na temelju ovoga možemo promatrati kako je $\mathbf{S} t$ jedan od praktičnih razvojnih koraka prema cjelovitom razlučivanju sanktorala, temporala kao i obrednih i zajedničkih misa u liturgijskim knjigama. ${ }^{33}$ Iako ovo, pogotovo u 12. stoljeću, nije nikakva revolucionarna značajka, ipak je posljedični pokazatelj razvoja liturgijskih knjiga prema misalu, kojemu je sakramentar tipološka baza iz koje se razvio.

31 Neki dijelovi sanktorala nalaze se i nakon f. 200 o čemu će još biti riječi. Radi se o kasnijim dodacima.

32 Usp. Liber Sacramentorum Romanae Ecclesiae Ordinis Anni circuli. (Cod. Vat. Reg. Lat. 316/Paris Bibl. Nat. 719. 1/56) Sacramentarium Gelasianum (RED, Series maior, Fontes IV), ur. L.C. Mohlberg - L. Eizenhöfer - P. Siffrin, Herder, Roma, ${ }^{3} 1981$.

33 Ovo je važan podatak, jer kodeks pod kataloškim brojem 625, trenutno poznatiji kao Splitski evanđelistar iz 12. stoljeća, (napomenimo da ga je dovoljno nazivati Splitski evanđelistar!) dakle suvremen St kodeksu, još uvijek ima slijed liturgijske godine u kojemu su dijelovi sanktorala inkorporirani u temporal. 


\subsubsection{Tipologija}

Tipološko ustrojstvo kodeksa $\mathbf{S t}$, ako ga usporedimo sa suvremenim liturgijskim knjigama, odnosno s knjigama od Tridentskoga Sabora do naših dana, praktično je istovjetno s misalima. Uostalom kako je rečeno $\mathbf{S t}$ dugo je vremena bio nazivan Missale Romanum. ${ }^{34}$ Zahvaljujući Š. Maroviću, barem u posljednja dva desetljeća, u Hrvatskoj znanstvenoj javnosti kodeks se počeo nazivati Sacramentarium Spalatense - Splitski sakramentar. Zašto sakramentar? Koja je razlika između misala i sakramentara?

Sakramentar je liturgijska knjiga koja sadrži sve dijelove misnoga slavlja potrebne predvoditelju slavlja, dakle tzv. predsjedateljske molitve i dijelove koji u lijepom i skladnom liturgijskom slavlju spadaju na predsjedatelja liturgijskoga slavlja. ${ }^{35}$ Predsjedatelj može biti biskup ili svećenik. Najveći dio formula u sakramentarima, a nerijetko i jedini, redovito su dijelovi za euharistijsko slavlje; mada nije neobično da sakramentar sadrži i predsjedateljske tekstove za ostale sakramente, posebno sakramentale, odnosno blagoslovine. Misal, iako se razvio iz sakramentara, sadrži sve potrebne dijelove misnoga slavlja; dakle osim predsjedateljskih molitava i čitanja, sadrži i pjevane dijelove predviđene za euharistijsko slavlje. ${ }^{36}$

\section{PORIJEKLO}

U samome kodeksu St nema niti jedne bilješke koja bi izravno govorila ili upućivala na mjesto, a još manje na vrijeme nastanka. ${ }^{37}$ Nema niti kalendara koji je obično dolazio na početku liturgijskih knjiga. Stoga ne čudi da je tradicionalno u splitskoj Crkvi držano, na temelju izvještaja Tome Arhiđakona, da je $\mathbf{S} \boldsymbol{t}$ donio nadbiskup Bernard iz Perugie koji je postao splitski nadbiskup oko 1200. godine. Svakako za vremensku dataciju najbolji je trag sam tip pisma u kodeksu sa svim specifičnostima. U potrazi za mjestom nastanka potrebno je stoga krenuti ponešto zaobilaznim putem, tj. od liturgijskih specifičnosti samoga kodeksa koje su nam dostupne. One se prvotno nalaze u sanktoralu, odnosno sloju svetačkih slavlja koji se nalaze u sakramentaru.

34 Usp. A. Badurina, Illuminated manuscripts in Croatia, 90-91; V. Novak, Notae paleographicae chronologicae et historicae I-VII, Vjesnik Arheološkog muzeja u Zagrebu, 15 (1928.), 159-222.

35 Usp. C. Folsom, I Libri liturgici romani, u: A. J. Chupungco (prir.), Scientia liturgica, sv. 1, Piemme, Casale Monferrato, 1998., 264.

36 Usp. C. Folsom, I libri liturgici romani, 283-289.

37 Usp. Š. Marović, Sakramentar riznice splitske katedrale, 65. 


\subsection{Vrijeme nastanka}

Gotovo sva dosadašnja istraživanja različitih autora suglasna su u mišljenju da je $\mathbf{S t}$ nastao polovinom 12 . stoljeća. ${ }^{38} \mathrm{~V}$. Novak je prvi koji je došao do toga zaključka na temelju paleografske analize, koja bi imala odgovarati stilu i tipu pisma koji je u Europi još uvijek prevladavao u 12 . stoljeću. ${ }^{39}$ D. Kečkemet kao povjesničar umjetnosti se također slaže s Novakovim mišljenjem. ${ }^{40}$ Ovu tezu još više pokušava utvrditi Š. Marović: na sličan dedukcijski način analizira i notne grafeme koji se pojavljuju u kodeksu te dolazi do zaključka da je tip notacije u $\mathbf{S t}$ beneventanska notacija koju je datirao u 12. stoljeće. Detaljnijim istraživanjem došlo se do izazova i poteškoća. Naime notni zapisi su očigledni kasniji dodaci, ali još uvijek u kronološkom smislu, dodani nedugo nakon nastanka kodeksa. Zanimljivo je što se zajedno na listovima koji sadrže notaciju, odnosno neume koje su beneventanske provenijencije, pojavljuju i dijelovi teksta pisani goticom, ispod samih neuma, ali također s elementima karolinške minuskule. Većina je autora goticu datirala u prvu polovinu 13. stoljeća. ${ }^{41}$ Postavlja se pitanje: kako su zajedno na istome listu dva različita tipa zapisa $\mathrm{k}$ tomu različito datirana, a očito su složena $\mathrm{u}$ kompaktnu cjelinu - tekst potpisan ispod neuma? Logičan odgovor je proširenje hipoteze, prema kojoj su ovi tipovi pisma u 12. i 13. stoljeću još uvijek paraleleno korišteni na području današnje južne Hrvatske. ${ }^{42}$ Možemo izvesti i sljedeću hipotezu: gotica, koja u 12. stoljeću počinje svoj razvitak već je prisutna i na istočnom Jadranu. Tako je moguće da je pisar teksta bio vješt u tada novome pismu dočim je pisar nota još uvijek koristio beneventanski tip.

U konačnici na temelju paleografskih zaključaka prethodnih studija, prema tipu pisma možemo se složiti s pretpostavljenim i široko prihvaćenim vremenom nastanka kodeksa koji ga smješta u polovinu 12. stoljeća. Kasniji dodaci svjedoče o čestoj uporabi i potrebi za prilagodbama, ili današnjim rječnikom rečeno ažuriranjima.

38 Prvotne pretpostavke su govorile o 13. stoljeću. Usp. Jelić - Bulić - Rutar, Vodja po Spljetu i Solinu, 105.

39 Usp. V. Novak, Scriptura beneventana s osobitim obzirom na tip dalmatinske beneventane, Sveučilišna knjižnica, Zagreb, 1920.

40 Usp. D. Kečkemet, Romaničke minijature u Splitu, Peristil: zbornik radova za povijest umjetnosti, 2 (1957.) 1, 129.

41 Novak je iznimka jer je datira u 14. stoljeće. Usp. Novak, Notae palaeographicae, 159-187. Prof. M. Stocchi, paleograf u Vatikanskim arhivima u analizi iz 2015. datirao ju je u 13. stoljeće.

42 Novak predmnijeva da su pisari, svaki osobno, istodobno koristili i beneventanu i goticu, pa su tako neizbježni utjecaji jednoga stila u drugi. 
3.1.1. Obrasci za slavlje sv. Franje Asiškoga i sv. Dominika listovi 201 i 202.

Ove obrasce možemo promatrati baš kao ažuriranja. Kako su i sv. Franjo Asiški i sv. Dominik živjeli, a i proglašeni svecima tek u 13. stoljeću, Franjo 1228. godine, a Dominik 1234., ${ }^{43}$ na prvi pogled ti bi obrasci pomicali vrijeme nastanka kodeksa najranije u četvrto desetljeće 13. stoljeća. No slijed teksta s f. 200v na 201r prekinut je, kao i s f. 202v na 203r: molitva Secreta od mise Pro benefactoribus defunctis, na f. 200v ne nastavlja se na f. 201r, već na f. 203r. ${ }^{44}$ Stoga je jasno da su ff. 200 i 203 starija dvolisnica, mada su i oni kasniji dodatak izvornom dijelu. Listovi 201 i 202 su očit kasniji dodatak koji je mogao biti dodan tek nakon 1234. godine te umetnut između listova 200 i 203. U općem kontekstu sanktorala u kodeksu St ovo je pokazatelj brzoga širenja štovanja svetih Franje i Dominika u Splitu i splitskoj Crkvi, pogotovo ako znamo da su već u prvoj polovini 13. stoljeća i franjevci i dominikanci imali samostane $u$ Splitu. ${ }^{45}$ Stoga je ovaj dio vjerojatno nadopisan polovinom ili nakon polovine 13. stoljeća.

\subsection{Mjesto nastanka}

\subsubsection{Galikanski utjecaji}

U kodeksu nema nikakve naznake mjesta odakle bi potjecao. ${ }^{46}$ Nema ni kalendara koji bi mogao olakšati potragu za mjestom nastanka. Analizirajući svetačka slavlja u sakramentaru, Š. Marović je došao do zaključka kako je St nastao na području Galije, današnje Francuske. ${ }^{47}$ Naime, u kodeksu imamo sloj svetaca koji su isključivo

43 Usp. J. Lang, Franziskus, Lexikon für Theologie und Kirche, sv. 4, Herder, Freiburg-Basel-Rom-Wien, 1995., 44-47; I.W. Frank, Dominikus, Lexikon für Theologie und Kirche, sv. 3, Herder, Freiburg-Basel-Rom-Wien, 1995., 319-320.

44 Molitva Secreta iz mise Pro benfactoribus defunctis u St, f. 200v: Suscipe Domine, haec munera pro animabus omnium nostrorum <re>qui- [f. 203r] (escentium benefactorum et pro) beneficiis eorum, quibus sustentamur; da eis retributionm in regno caelorum. Dijelovi u zagradi su izblijedjeli u St, stoga smo za ponovno uspostavljanje teksta koristili seriju Corpus Orationum. Usp. Corpus Orationum, sv. 9, br. 5728, u: Corpus Christianorum Series Latina, sv. 160 H, ur.: B. Coppieters't Wallant, Brepols, Turhout, 1986., 94.

45 Usp. F. Šanjek, Crkva i kršćanstvo u Hrvata. Srednji vijek, Kršćanska sadašnjost, Zagreb, ${ }^{2}$ 1993., 280-305.

46 Usp. Š. Marović, Sakramentar riznice splitske katedrale, 65.

47 Usp. Isto, 66. S druge strane, Badurina mjesto nastanka smješta na sjever Italije. Na temelju svega dosada rečenog, držimo da Badurinina hipoteza ne može biti točna. Usp. A. Badurina, Illuminated manuscripts in Croatia, 91. 
štovani na području Galije: Kristofor i Kukufat (f. 112 v), German Germanus (f. 112bis r), Leodegar (f. 130 r), Krispin i Krispinijan (f. 132 r), Lazar (f. 140 r). Ti sveci daju dubok galski pečat sakramentaru. ${ }^{48}$ No, Galija, odnosno područje današnje Francuske, još uvijek je izuzetno širok i velik prostor. Stoga smo u hodu prema traženju mjesta nastanka kodeksa precizirali još jednu referentnu točku: liturgijski obrazac (formular) za slavlje sv. Leodegara. Usporedbama sa srednjovjekovnim liturgijskim izvorima ustanovili smo da formular za slavlje sv. Leodegara postoji i u Missale Gothicum, koji je zapravo liturgijska knjiga galikanske liturgije. Obrazac iz Missale Gothicum je različit od onoga u St. ${ }^{49}$ Dapače Zborna molitva - Oratio Collecta slavlja sv. Leodegara, kako je nalazimo u St, do sada je nepoznata! ${ }^{50}$ Nismo je pronašli niti u jednome liturgijskom izvoru, kao ni u velikom slijedu u kojemu su sabrane sve poznate liturgijske molitve iz sakramentara i misala, Corpus Orationum. ${ }^{51}$ Molitva se $u$ do sada istraženim izvorima nalazi samo u St na f. 130r, čime naš kodeks dobiva još više na posebnosti i povijesnoj važnosti i u svjetskim razmjerima, kao jedinstveni svjedok ove liturgijske molitvene formule:

Oratio. Deus, qui praesentem diem honorabilem nobis in beati Leodegarii episcopi et martyris tui passione fecisti, da Ecclesiae tuae de tanto pontifice gaudere, ut apud misericordiam tuam exemplis eius adiuvemur et meritis. Per. ${ }^{52}$

48 Usp. Š. Marović, Sakramentar riznice splitske katedrale, 66.

49 Missale gothicum $\mathrm{n}^{\circ} 425$ - 431, ur. L. C. Mohlberg (Rerum Ecclesiasticorum Documenta, Series Maior, Fontes 5), Herder, Roma, 1961., 104-106.

50 Marović za njih ne donosi nikakav izvor. Usp. Š. Marović, Sakramentar riznice splitske katedrale, 75-77. U budućnosti namjeravamo obraditi i takve jedinstvene, unikatne liturgijske obrasce u St.

51 Corpus Orationum, u: E. Moeller - I. M. Clément - B. Coppieters't Wallant (prir.), Corpus Christianorum Series Latina, sv. 160-160M, Brepols, Turnhout, 1992.-2004.

52 Iako je obrazac jedinstven i u ovakvom se obliku ne pojavljuje u drugim izvorima, radi se o tzv. "čentonskom" obrascu. Takvi molitveni obrasci nastaju kompilacijom pojedinih sintagmi ili dijelova već poznatih molitvenih obrazaca. Neki dijelovi od kojih je sastavljen naš obrazac poznati su iz ranijih obrazaca, a možemo ih naći u izvorima: Sakramentar iz Verone, br. 251, Gelazijeuski sakramentar, br. 901 i Grgurov sakramentar, br. 574: Deus qui praesentem diem honorabilem nobis in beati iohannis nativitate fecisti, da populis tuis spiritalium gratiam gaudiorum, et omnium fidelium mentes dirige in viam salutis aeternae; te ponovno Gelazijevski sakramentar, br. 860 i Grgurov sakrametar, br. 776: Deus qui es sanctorum tuorum splendor mirabilis, qui hunc diem beati andreae martyrio consecrasti, da ecclesiae tuae de eius natalicia semper gaudere ut apud misericordiam tuam exemplis eius protegamur et meritis. 
Za ovo slavlje u izvorima su posvjedočene molitve, iz obrazaca $\mathrm{u}$ Missale Gothicum (MG), a različite od ove u St. ${ }^{53}$ Pored $M G$, koji je izvor galikanske liturgije, jednaku molitvu kao i u njemu nalazimo još u izvorima: Missale Gemmeticensis (vjerojatno iz Engleske, Winchestera), ${ }^{54}$ Sacramentarium Rhengauiense (Sakramentar iz Rheinaua, Njemačka), ${ }^{55}$ te u Missale ad usum Ecclesiae Westmonasterii (iz Westmintera, Engleska). Sveti Leodegar je bio biskup i mučenik u Autunu (sjeverozapadna Francuska) u 7. stoljeću. ${ }^{56}$ Posredno promatranje ovih izvora koji nam svjedoče geografsku raširenost štovanja sv. Leodegara otkriva moguće utjecaje s britanskoga otočja i na St. Ipak ne smijemo zanemariti činjenicu kako je molitva iz St posve različita od one u navedenim izvorima. Nadalje oblik i struktura molitve u St su tipično rimskoga tipa, rimske liturgije. Liturgijski kontekst cjelokupnoga sakramentara, kao i sami tekstualni sadržaj molitve to svjedoči: cijeli $\mathbf{S t}$ je pod jakim utjecajem grgurovske i gelazijevske tradicije rimskih sakramentara. Također $\mathbf{S t}$ sadrži i neke obrasce iz Pontificale Romano-Germanicuma. ${ }^{57}$ Promatrajući sve ove premise zajedno možemo ustvrditi kako je St franko-rimska liturgijska knjiga. Time dolazimo do hipoteze da je kodeks $\mathbf{S t}$ nastao na području pod utjecajem Svetoga Rimskoga carstva polovinom 12. stoljeća.

Vodeći računa i o vremenu nastanka i o prisustvu sv. Leodegara u kodeksu, kao i ostalim galikanskim svecima ${ }^{58}$ te naposljetku o rimskoj liturgijskoj tradiciji prisutnoj u sakramentaru možemo mjesto nastanka sužavati pa posljedično doći do zaključka kako je $\mathbf{S t}$ nastao negdje na području današnje središnje ili južne Francuske. Na tom području možemo naći $u$ istom kontekstu i vremenu rečene premise, odnosno rimsku liturgiju s jakim galikanskim pečatom. No i to je još uvijek poprilično veliko i neprecizirano područje.

53 Usp. Corpus Orationum $\mathrm{n}^{\circ}$ 1455, u: Corpus Christianorum Series Latina 160 A, 260. Navedena formula je Collectio. Missale gothicum $\mathrm{n}^{\circ} 426$, ed. Mohlberg (Rerum Ecclesiasticorum Documenta, Fontes 5), 104.

54 Usp. Corpus Orationum, u: Corpus Christianorum Series Latina 160 A, XX.

55 Usp. Sacramentarium Rhenaugiense, u: A. Hänggi - A. Schönherr (prir.), Spicilegium Friburgense 15, Universitätsverlag, Freiburg, 1970., 49-53. Ibid. $\mathrm{n}^{\circ}$ 886, 194.

56 Usp. Martyrologium Romanum ex decreto Sacrosancti Oecumenici Concilii Vaticani II instauratum auctoritate Ioannis Pauli PP. II promulgatum. Editio altera, Libreria Editrice Vaticana, Città del Vaticano, 2004., 550.

57 Usp. Š. Marović, Sakramentar riznice splitske katedrale, 69. Rimsko-germanski pontifikal-Pontificale Romano Germanicumje nastao u Mainzu tijekom 10. stoljeća.

58 Usp. G. Gresser, Leodegar, Lexikon für Theologie und Kirche, sv. 6, 831. 


\subsubsection{Hispanski utjecaj}

Daljnji korak u preciziranju mjesta nastanka jest na prvi pogled uobičajen liturgijski obrazac na f. 139r u St. Liturgijski obrazac je naslovljen Eulaliae martyris - slavlje svete Eulalije mučenice. ${ }^{59}$ Ova svetica se spominje također i u $M G .{ }^{60}$ Usporedba je pokazala kako se obrasci za slavlje svete Eulalije mučenice u $\mathbf{S} t$ i u $M G$ razlikuju, dapače nemaju niti strukturalne sličnosti. Razlozi su već navedeni u primjeru sv. Leodegara. Naime liturgijski obrazac svete Eulalije u St jest iz gelazijevske (dakle rimske) liturgijske tradicije, ali ga u toj tradiciji nalazimo u slavlju svete Felicite. Nalazi se u Gelazijanskom sakramentaru GeV 1070 - 1072.

Radi lakšega praćenja usporedno donosimo oba obrasca:

\begin{tabular}{|c|c|}
\hline GeV 1070 - 1072 & St f. $139 r$ \\
\hline $\begin{array}{l}\text { In natale sanctae Felicitatis. } \\
\text { Item VIIII kalendas Decembris }\end{array}$ & Eulaliae martyris \\
\hline $\begin{array}{l}1070 \\
\text { Intercessio nos, quaesumus, } \\
\text { domine, sanctae Felicita- } \\
\text { tis martyrae tuae uotiua con- } \\
\text { foueat, ut eius sacrata natalicia } \\
\text { et temporaliter frequentemus et } \\
\text { conspiciamus aeterna: per. }\end{array}$ & $\begin{array}{l}\text { Intercessio nos, quaesumus, } \\
\text { domine, sanctae Eulaliae martyr- } \\
\text { is tuae uotiua confoueat, ut eius } \\
\text { sacrata natalicia et temporali- } \\
\text { ter frequentemus et conspicia- } \\
\text { mus aeterna. Per Dominum. }\end{array}$ \\
\hline $\begin{array}{l}1071 \\
\text { Secreta. Munera tibi, domine, } \\
\text { pro sanctae Felicitatis gloriosa } \\
\text { commemoracione deferimus, } \\
\text { quae nobis huius solempnitatis } \\
\text { effectu et confessionem dedi- } \\
\text { cauit et sanguinem: per. }\end{array}$ & $\begin{array}{l}\text { Secreta. Munera tibi, domine, } \\
\text { sanctae Eulaliae gloriosa com- } \\
\text { memoracione deferimus, quae } \\
\text { nobis huius solempnitatis } \\
\text { effectum et confessionem dedi- } \\
\text { cauit et sanguine. Per. }\end{array}$ \\
\hline $\begin{array}{l}1072 \\
\text { Post communionem. Praesta, } \\
\text { domine, quaesumus, ut sacra- } \\
\text { menti tui participatione uegitati } \\
\text { sanctae Felicitatis quoque mar- } \\
\text { tyris praecibus adiuuemur: per. }\end{array}$ & $\begin{array}{l}\text { Post communio. Praesta, domine, } \\
\text { quaesumus, ut sacramenti tui } \\
\text { participatione uegetati sanctae } \\
\text { Eulaliae quoque martyris praeci- } \\
\text { bus adiuuemur. Per Dominum. }\end{array}$ \\
\hline
\end{tabular}

59 Sveta Eulalija, hispanska mučenica, mučena je za Dioklecijanova progonstva u Meridi. Spomendan joj se slavi 10. prosinca. Suzaštitnica je Crkve u Barceloni. Usp. O. Engels, Eulalia, Lexikon für Theologie und Kirche, sv. 3, 986.

60 Missale gothicum $\mathrm{n}^{\circ}$ 138-142, ed. L.C. Mohlberg (Rerum Ecclesiasticorum Documenta, Fontes 5), 40-42. 
Razlike u obrascima, osim svetačkih imena, su ponešto stilske naravi, uz neke varijacije u prijepisima što nije neobično u srednjovjekovnim izvorima. Nije neobično ni to da se jedan obrazac koristio za više različitih svetačkih slavlja, naravno prilagođujući ime sveca. U St ime je promijenjeno sukladno običajima mjesta gdje se slavio blagdan sv. Eulalije. Njezino je štovanje gotovo isključivo prisutno u Hispaniji, a posebno u Barceloni. ${ }^{61}$ Stoga u St imamo i hispano mozarapske liturgijske utjecaje.

\subsubsection{Mjesto nastanka}

Iz gornjih premisa izvodimo sljedeće tvrdnje: $\mathbf{S t}$ po formi i tipologiji jest sakramentar rimskoga tipa i to gelazijanizirani grgurovski sakramentar (gregoriano gelasianisato); potom smo ustanovili sloj galikanskih svetaca te konačno obrazac svete Eulalije koji nam pokazuje utjecaj s Iberskoga poluotoka. Jezikom matematike, imali smo jednadžbu kojoj smo otkrivali nepoznanice koje nam u konačnici otkrivaju rješenje, odnosno mjesto nastanka kodeksa St. Dakle, imamo premise:

- Knjiga rimske liturgije

- Galikanski sveci

- Sveta Eulalija iz Barcelone - hispanski utjecaj

Galikanski sveci i hispanska svetica mogu se u razvijenom srednjem vijeku, odnosno u vrijeme nastanka kodeksa (12. stoljeće), nalaziti unutar obrazaca rimske liturgije samo u južnoj Francuskoj. To je jedino geografsko područje dodira rimske i hispanske liturgije, a razloge prisutnosti galikanskih svetaca u južnom dijelu današnje Francuske nema potrebe detaljnije objašnjavati. Štovanje svete Eulalije na tome području posebno je prisutno na području između Narbone i Montpelliera, pogotovo u gradu Beziersu. U njemu je još od ranoga srednjega vijeka postojala crkva posvećena svetoj Eulaliji. Zaključujemo stoga kako je $\mathbf{S t}$ nastao na rečenom području, vjerojatno baš u Beziersu.

\subsection{Od mjesta nastanka do Splita}

Kodeks je vjerojatno nastao za neku od crkava u južno-francuskom području. S druge strane vidljivo je da su notni zapisi kasni-

61 Usp. F. Fita, Eulalia of Barcelona, u: The Original Catholic Encyclopedia 5, ur. C. G. Herbermann i dr., Robert Appleton company, New York, 1915., 603; Missale gothicum, ed. L.C. Mohlberg (Rerum Ecclesiasticorum Documenta, Fontes 5), XXIIII. 
ji dodatak izvornom kodeksu beneventanskoga tipa. Područje na kojemu se koristila beneventana u geografskom smislu je dosta ograničeno: koristila se u južnoj Italiji (Beneventana Cassinense i Beneventana Barese) te u područjima današnje južne Hrvatske, na području Dalmacije (tip Beneventana Dalmata). U vrijeme nastanka kodeksa ni u kojem slučaju ne možemo je smjestiti u transalpinska područja ni sjeverno ni zapadno od Alpa, tj. niti u današnju Njemačku i Švicarsku niti u Francusku. ${ }^{62}$ Notni zapisi kako smo vidjeli, datirani su u 12. stoljeće: stoga je jedini zaključak da je nedugo nakon nastanka kodeks St prenošen dalje te je stigao u područje na kojem se koristila beneventana, da bi naposljetku stigao u Split u kojemu je i ostao do danas. Iz povijesnih vrela nije moguće utvrditi kako i kada je kodeks stigao u Split. Imajući na umu i spomenute paleografske odrednice, odnosno dodatke pisane goticom u 13. stoljeću dalo bi se naslutiti da se to dogodilo najkasnije već u drugoj polovini 12. stoljeća. Na temelju podataka koje nam je donio Toma Arhiđakon, tradicionalno se, ali opet ne bez osnove, uvriježilo mišljenje da je St stigao u Split iz Bologne, ${ }^{63}$ i da ga je donio nadbiskup Bernardo koji je tamo bio i profesor. ${ }^{64}$ Pretpostavka se čini logična u okvirima tadašnjeg vremena jer veze Splita sadrugom stranom Jadrana nisu nikakva novost.

\subsubsection{Sv. Stjepan Ugarski}

U sadržaju kodeksa ipak postoji izazov koji dovodi u pitanje uvriježenu tradiciju. U St na f. 204r imamo liturgijski obrazac za slavlje Sv. Stjepana kralja - kako doslovce stoji upisano: In sancti Stephani regis. Iako ga i Marović izričito navodi, ne ulazi u njegovu hagiografsku i povijesno liturgijsku analizu. ${ }^{65}$ Tekstualna analiza molitava ovoga obrasca pokazuje kako se radi o sv. Stjepanu Ugarskom iz 11. stoljeća, a to nedvojbeno pokazuje Oratio collecta iz obrasca slavlja sv. Stjepana:

Deus qui beatum Stephanum confessorem tuum terreni imperii gloria coronasti, et sanctorum tuorum societate sublimasti, praesta, quaesumus, ut quem Pannonia

62 Usp. E. A. Loew - V. Brown, The beneventan script. A history of the south Italian minuscule, Edizioni di Storia e letteratura, Roma, ${ }^{2} 1980 ., 47-83$.

63 Usp. I. Armanda, Splitski nadbiskup i teološki pisac Bernard iz Perugie, Kulturna Baština, 37 (2011.), 34-35.

64 Usp. Š. Marović, Sakramentar riznice splitske katedrale, 65-66.

65 Usp. Isto, 79. 
meruit habere divinae religionis doctorem in terris, eum modo Ecclesia tua mereatur habere defensorem in caelis. Per. ${ }^{66}$

Kodikološka analiza sveščića u kojemu se nalazi ovaj obrazac pokazala je nedosljednosti, što dokazuje kako je cijeli obrazac kasnije dodan: po stilu pisma kojim je pisan taj obrazac, vidi se da je ga je pisala druga (treća ili četvrta...) ruka. Nepostojanje ovoga obrasca i molitve u liturgijskim izvorima porijeklom iz Italije i iz Francuske, ${ }^{67}$ upućuju nas na jedini mogući zaključak, a to je da je kodeks bio u Ugarskoj ili barem na području jakoga ugarskoga utjecaja. Južna Hrvatska prije Zadarskog mira nije bila pod takvim ugarskim utjecajem kao sjeverna Hrvatska - pogotovo u crkvenom smislu. Stoga zaključujemo da je $\boldsymbol{S} \boldsymbol{t}$ barem jedno vrijeme tijekom druge polovine 12. stoljeća bio u Ugarskoj.

Nadalje Toma Arhiđakon nam svjedoči da je nadbiskup Bernardo često bio na dvoru Ugarskih kraljeva Bele III. i njegova nasljednika Emerika. Imamo stoga jasan povijesni i geografski okvir unutar kojega je lako moguće, dapače i vjerojatno kako je baš nadbiskup Bernardo donio St u Split gdje je ostao do danas. Toma svjedoči da je nadbiskupa kralj obasipao počastima i mnogim darovima. ${ }^{68}$ Iako nijedan dar nije preciziran, nije nemoguće da bi među tim darovima bila i pokoja knjiga, dakle i kodeks St. Imajući na umu prisutnost dalmatinske beneventane u kodeksu, datirane u 12. stoljeće, zajedno s ugarskim utjecajima, logično se čini povezati ovaj kodeks s nadbiskupom Bernardom koji je, kako svjedoči Toma Arhiđakon, i prije nego je postao nadbiskup, često išao na dvor ugarskoga kralja. ${ }^{69}$ To se uklapa i u vremenski okvir nastanka beneventanskih notnih zapisa u St. Stoga nam se izvjesnim čini da je tijekom posljednjih desetak godina 12. stoljeća Bernardo donio $\mathbf{S} \boldsymbol{t} \mathrm{u}$ Split, gdje su kodeksu za potrebe mjesne Crkve vrlo brzo dodavani neki dijelovi - konkretno notni zapisi, a kasnije tijekom povijesti i ostali dodaci. Dakle u Split je St stigao iz Ugarske, i vjerojatno ga je donio Bernardo kada još nije bio biskup.

66 Dosada je molitva poznata uglavnom iz kasnosrednjovjekovnih izvora 14. i 15 stoljeća. Usp. J. Danko, Vetus Hymanrium Ecclesiasticum Hungariae, Budimpešta, 1893., 88.

67 Usp. Corpus Orationum, u: Corpus Christianorum Scriptorum Latinorum, sv. 160160M.

68 Usp. Toma Arhiđakon, Historia Salonitana, ur. O. Perić - M. Matijević Sokol - R. Katičić, Književni krug, Split, 2003., 83.

69 Usp. Toma Arhiđakon, Historia Salonitana, 82. 


\section{ZAKLJUČAK}

Svaki srednjovjekovni rukopis jest poseban i jedinstven na svoj način. Mada ga možemo svrstati u poznatu i razgranatu grupu rimskih sakramentara tzv. grgurovskih gelazijaniziranih sakramentara, uočene značajke u kodeksu St još ga više uzdižu u rečenoj jedinstvenosti. Podaci koje smo obradili daju nam nove spoznaje i bacaju novo svjetlo na povijest tog zanimljivoga kodeksa, ali i grada Splita, kao npr. njegov put od mjesta nastanka do Splita. Iako su mnoge stvari o povijesti i liturgijskim značajkama još nejasne i tek se trebaju otkriti, Splitski sakramentar ostaje značajan spomenik cjelokupnoga, a ne samo crkvenoga splitskoga srednjovjekovlja. Također je i spomenik i pokazatelj vrlo aktivnoga života Splitske Crkve u razvijenom srednjem vijeku kao i njezinih veza ne samo sa suprotnom obalom Jadrana, već i sa sjeverom, odnosno tadašnjom Ugarskom. Želja nam je u budućnosti predstaviti i cjelokupni tekst kodeksa, iz kojega bi se mogle izvući daljnje spoznaje i upotpunjavati povijesne i liturgijske značajke - ne samo za splitsku povijest, već i cjelokupnu povijest Crkve u Hrvatskoj, ali kako smo vidjeli i mnogo šire, preko današnje Mađarske, možda i Italije, Francuske pa sve do Iberskoga poluotoka.

\section{FEATURES AND ORIGIN OF THE SACRAMENTARY OF SPLIT}

\section{Summary}

A very valuable medieval manuscript codex, kept in the cathedral archives of the cathedral of Split, typified by mo. Šime Marović as the Sacramentary, has often been the subject of studies by various scholars. The knowledge of it and its specific features slowly complemented each other. As it is a liturgical book, it is strange that this aspect of this unique book has not been sufficiently explored. In addition to the conclusions drawn from the past research and studies, many questions remain open. One of them is the origin of the Sacramentary: so far there has been a common hypothesis that it was probably brought to Split from Bologna by Archbishop Bernardo. Through a detailed analysis of the liturgical and codicological structure of the Sacramentary, and the discoveries of its extraor- 
dinary, even unique, properties, we have come to the conclusions about the origin of this book, about the liturgical influences that have largely shaped the content, and finally how the Sacramentary itself reached Split.

Keywords: Sacramentary of Split, codex, Roman liturgy, Gallican liturgy, Hispano-Mozarabic liturgy 